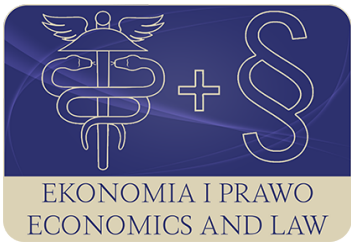

EKONOMIA I PRAWO. ECONOMICS AND LAW

Volume 16, Issue 1, March 2017

p-ISSN 1898-2255, e-ISSN 2392-1625

www.economicsandlaw.pl

EKONOMIA I PRAWO
ECONOMICS AND LAW

ORIGINAL ARTICLE

received 22.11.2016; revised 23.01.2017; accepted 31.03.2017

Citation: Antonów, D. (2017). Influence of stamp duty on undertaking and running economic activity. Ekonomia i Prawo. Ecomomics and Law, 16(1): 5-19.

doi:10.12775/EiP.2017.001.

\title{
Influence of stamp duty on undertaking and running economic activity
}

\author{
DOBROSEAWA ANTONÓW \\ University of Wrocław, Faculty of Law, Administration and Economics, Department of Financial \\ Law, ul. Uniwersytecka 22/26, 50-145 Wrocław, Poland \\ $\square$ dobroslawa.antonow@uwr.edu.pl
}

\begin{abstract}
Aim: The article is devoted to stamp duty issues. The problem analysis of legal construction of this public levy with paying special attention to its influence on undertaking and running economic activity has been carried out in the article.

Motivation: The stamp duty is one of the performances, which a taxpayer-entrepreneur is burdened with; and thereby, the stump duty is one of the costs of running economic activity. The cost is regulated mainly in the situation when the entrepreneur requests to carry out an official action, a permit or a certificate concerning his individual business from the public administrative agencies.

Results: Undertaking and running economic activity in accordance with the legal rules in force are conditioned by such official actions. Therefore, the stump duty is the entrepreneur's basic cost connected with the organization of legally run economic activity. Little interest of the levy law doctrine in public charges issues, especially slight achievements in the topic of special situation of the entrepreneur as a subject burdened with many different charges, mainly all the administrative charges among other things has been the grounds for the undertaken research.
\end{abstract}

Keywords: charge; stamp duty; economic activity; procuration; permit

JEL: G3; H2

\section{Introduction}

Public levies, in that particularly taxes, show close connection with the economy (Mastalski, 2014, p. 4). In the doctrine it has been emphasized that the fundamental condition of the appropriate functioning of tax system is a clear concept 
of economic effects of taxation. This means the appropriate use of taxes to influence on the economy by the State (Mastalski, 2014, p. 35). Although the taxes are the levies, which at present play the most important role, and their subjective and objective scope is much wider than of other public levies (Mastalski, 2014 , p. 3), yet also other levies exist, the public charges among other things. The charges, definitely more poorly researched and described in the doctrine than the taxes, are also omitted when the public levy affecting the economy has been assessed: the undertaking and running economic activity among other things. Yet, the charges are also the cost of running economic activity (Antonów, 2016a, pp. 537-546). Furthermore, apart from the fiscal function, the charges also fulfil economic and public functions affecting the decisions concerning undertaking and running economic activity.

Incurring of performances for public benefit, among other things the taxes, determined under the Act, belongs to the human and citizen's obligations expressed in Article 84 of the Polish Constitution (1997). In the regulation the taxes are listed as a category of performances for public benefit only as an example; however, the regulation is also applied to other levies, the public charges among other things (Banaszak, 2012, p. 489). The right of the State to collect the public levies is limited by the principle of the freedom of economic activity assessed as one of the grounds to form the law limits of taxation (Krzywon, 2011, p. 99). Article 20 of the Constitution constitutes the principle of freedom of economic activity. The Freedom includes freedom of choice of economic activity and freedom of carrying out and withdrawing from economic activity (Banaszak, 2012, p. 161). The principle of freedom of economic activity determines to the legislator interdiction of arbitrary interference in the proceedings sphere of business entities and the order of taking actions intended to protect the freedom (Ciapata, 2001, p. 15). The principle also concerns the legislative actions in the range of public levies burdening economic activity. Therefore, it is assumed that the constitutional limits of freedom of economic activity are developed together under the regulations of the Constitution concerning the resting with everybody obligation to pay the taxes and other public levies (Krzywoń, 2011, p. 101).

In order to assess, in what way the particular public levies affect the economic decisions it is necessary to carry out the analysis of their legal constructions. The present article is devoted to such analysis of one of the public charges the stump duty (as determined under the Act on Stamp Duty (2006) - from its influence on undertaking and running economic activity point of view. Purposes of the article can be divided into purposes of general and detailed nature. The general purpose is to point out the importance of public charges in developing economic decisions as well as indicating the directions of the analysis of public charges construction from their influence on undertaking and running economic activity point of view. The detailed nature purpose is an attempt to determine whether and what kind of influence the stump duty has on undertaking and running economic activity. Choosing the stump duty for this analysis needs 
arose due to its widest objective and subjective scope, it is the most common charge and it is determined as the common administration charge.

\section{Research method}

The article has been written pursuant to a typical for law sciences formal-dogmatic method. It shows the problem analysis of the legal act - the Stamp Duty Act. In the analysis it has been assumed the need of taking charges in the general structure of the public entrepreneur's burdens into consideration. Justification for such research is the fact that in the Polish law doctrine not much space has been given to research into charges and; all the more, their importance while making decisions on undertaking and running economic activity is omitted. The analysis of the regulations by law concerning the entrepreneur as a subject burdened with public obligation by virtue of a stamp duty shows that special regulations occur in the legal construction, with which the legislator attempts to affect entrepreneur economic decisions. The detailed decisions in the above range carried out on the basis of the prescriptive analysis can be the grounds for analysis of the influence also from the economical point of view of the enterprise. The analysis also is the grounds for formulating de lege lata and de lege ferenda conclusions as regards the questions of the stamp duty of public charges in general.

\section{Stamp duty as the common administration charge}

It is required to determine the place of stamp duty among other public levies in order to assess its influence on undertaking and running economic activity. The arrangements in this range point out the categories of the entrepreneurs' activities, which may be the stamp duty object.

The stamp duty is classified as a common administrative charge (Antonów, 2014, p. 376). The stamp duty construction allows to make an assumption that it is a payment on account of official actions administered by the public administrative agencies at a taxpayer's request. Therefore, whenever entrepreneur, who runs his own economic activity, will declare or apply for carrying out of administered by the public administrative agencies official action on account of his economic activity within an objective scope of the Stamp Duty Act, he becomes a taxpayer of a stamp duty and the stamp duty is one of the costs of the run activity. Official action administered at individual cases within the public administration agencies range on request or declaration, issuing a certificate on request, issuing a permit (authorization, licences) as well as submission of a document that states giving a power of attorney or procuration at the range of the cases connected with the public administrative agency action or with the court proceedings (Art 1 of the Stamp Duty Act) are included into the objective scope of stamp duty. The detailed list of the stamp duty objects has been shown in Annex to the Stamp Duty Act (Art. 4 of the Stamp Duty Act). The range of official actions shown in the Annex is of open nature (in the Annex to the Stamp 
Duty Act the rates of stamp duty for other than listed in the Annex decisions, certificates, permits (authorizations, licences) - 53 part I of Annex, 21 part II of Annex, 44 part III of Annex are provided). The Annex includes a wide-ranging catalogue of official actions, the essence of which is regulated on the basis of many regulations by law of different branches of the legal system (for example, making an entry in the register of the controlled activity of the subject executing the activity on the basis of the rules relating to the traffic regulations, a permit for the turnover of the waste with foreign countries on the basis on regulation under the Act on international movement). Therefore, the legal construction of a stamp duty permits to encompass a wide-ranging catalogue of official actions both the indicated by the name in the Stamp Duty Act and the settled on the basis of other Acts, meeting the criteria defined in the Stamp Duty Act unless other charges are not taken for the actions (Art. 3 of the Stamp Duty Act). Therefore, the stamp duty should be assessed in categories of public-legal performance which the entrepreneur incurs due to initiation of official actions by the public administrative agencies. The necessity of distinguishing the names concerning the taxpayer and tax obligation regarding the obligation by virtue of charges results from the theory of charges. That is why it should be emphasized at the beginning that the use of the term entrepreneur as 'a stamp duty taxpayer' in the article is only of symbolic nature and means 'legal-public duty by virtue of the stamp duty, which entrepreneurs are burden with'.

\section{Notion of economic activity in the Stamp Duty Act}

The title of the article unambiguously orients the analysis of the legal construction of stamp duty to its assessment from the economic activity point of view. This generates a need to determine the economic activity notion on the grounds of the Stamp Duty Act. It is emphasized on the grounds of the tax law doctrine that the legislator while forming the taxation range is permitted latitude in using civil law and law on public economic activities institutions issue - taking the institutions as defined by binding in the fields of the law system or modifying them separately for his own needs (Mastalski, 2003, p. 13). This also concerns the notion of the economic activity. The above regularity is relevant not only on the grounds of the regulations by law at the range of the tax law, but also at the levy law, in this the regulations concerning charges.

The notion of the economic activity on the grounds of the Stamp Duty Act is used by the legislator in a few terms. Firstly, the legislator uses the notion of the economic activity without giving its definition. Secondly, the legislator refers to different kinds of economic activity indicating its specific branch or individualizing it in another way. Thirdly, the legislator uses the categories of the object of stamp duty, that by nature concern only entrepreneurs (procurations, licences) also literally the legislator does not refer to the notion of economic activity. 
In relation to the first issue, it should be indicated that the notion of economic activity has not been defined in the Stamp Duty Act. The legislator uses the notion (or only the notion of activity in the meaning of economic activity) in the Annex to the Stamp Duty Act when he needs to define the detailed list of the stamp duty objects. As an example, in Paragraph 44 part III of the Annex, the rate of stamp duty for other than listed in the Annex permits (authorization, licences) with distinguishing the permits for running economic activity and others has been provided. At the same time the regulation can be an example of using the notion of economic activity in the widest term without indicating a category of such activity. Since the legislator did not define the notion of economic activity on grounds of the Stamp Duty Act, this means that the notion should be interpreted both on grounds of the Stamp Duty Act Paragraph 44 part III of the Annex and in other regulations by the legislator, according to the definition of the notion in the Act on freedom of economic activity (2004). In the doctrine it is assumed that the Act is of a basic nature in the range of issues connected with the realization of the principle of economic freedom, but the definition of the economic activity placed in the Act is of general nature (Borszowski, 2010, pp. 28-29). The above view has been confirmed by the law court's decisions, where it is indicated that in the regulation it is not the issue of running every kind of activity, but exclusively of the economic activity as defined under the Freedom of Economic Activity Act (Judgement of WSA in Wrocław of 28 September 2010; II SA/Wr 387/10).

In the second term, the legislator uses the economic activity notion specifying it more precisely with concurrent indicating the object of activity (for example, the economic activity within the scope of fuel and energy turnover with foreign countries - 34 part III of Annex to the Stamp Duty Act) or specifying it in another way (for example, the economic activity being subject to entry in the register of controlled activity - 36 part I of Annex to the Stamp Duty Act). Making the issues in the scope more detailed is aimed at the differentiation of the burden of stamp duty depending on the kind of economic activity.

As far as the third of the listed aspects is concerned, the legislator admittedly does not use the notion on economic activity, but he (the legislator) forms the regulations determining the tax obligations in such a way that the regulation may concern solely entrepreneurs. Determined in Article 1 of the Stamp Duty Act the stamp duty object - submission a document stating issuing a procuration can be an example. The procuration in accordance with article $109^{1}$ of the Civil Code (1964) is the proxy given by an entrepreneur being subject to entry in the register on entrepreneurs.

Just as the notion of economic activity, the legislator uses the notion of entrepreneur in the Stamp Duty Act, but again, without giving the definition on the entrepreneur. By analogy, it should be made an assumption that the entrepreneur in the meaning of the Stamp Duty Act is the entrepreneur in the meaning of the Freedom of Economic Activity Act. The above assumption confirms the context of using the notion in the Stamp Duty Act since the legisla- 
tor used the notion of entrepreneur in Article 1 of the Stamp Duty Act and then, in the Annex to the Stamp Duty Act he indicates the categories of entrepreneurs (for example, the oversea entrepreneur - 29 part I of the Annex, the entrepreneur carrying out activity in the range of ethyl alcohol production - 36 part I of the Annex, microentrepreneurs (small businessmen), small and average entrepreneurs - 40 part I of the Annex) as well as the category of the entities that are not entrepreneurs in the meaning of the regulations of the freedom of economic activity (36a part I of Annex). The last category shows that whenever the legislator speaks in the Stamp Duty Act about entrepreneurs he means the entrepreneurs in the meaning of the Freedom on economic activity.

The formulation of Article 5 of the Stamp Duty Act permits to assume that each entrepreneur may be the stamp duty taxpayer irrespective of the organization form of run by him activity (body persons, entity persons and some establishments without the status of a legal person). The legislator did not provide any entity-related exemptions dedicated to entrepreneurs, either. This means that the obligation by virtue of stamp duty is of the common nature to that effect that it concerns all entrepreneurs.

\section{Legal construction of the stamp duty - the problem analysis from the taxpayer-entrepreneur's point of view}

Carrying out the analysis of the legal construction of the stamp duty (especially its subject) from the entrepreneur as the stamp duty taxpayer's point of view, the following regularities can be noticed.

At first, going by the criterion of the person who is a taxpayer-entrepreneur, three different categories of activities included in the range of the objective scope of the Stamp Duty Act should be indicated. Activities that are not related with the economic sphere, but with the personal taxpayer's sphere belong to the first category. Decisions taken by the Head of Registry Office (1 and 2 part I of Annex) are the examples of this category of activities. The categories of the stamp duty subjects, which of their nature concern solely the sphere of activities connected with undertaking and running economic activity are the second category of activities. Carrying out the entry of oversea enterprise's representation in a register of the oversea enterprise's representation (29 part I of Annex), a permit for an initiation of the bank in the form of a joint-stock company (15 part III of Annex) or the action or submission a document stating issuing a procuration (Art. 1, 1 point 2 of the Stamp Duty Act) are the examples of this category. Activities, that among others may, but not necessary, concern the entrepreneurs, are the third category. Approval of a building design (10 part I of Annex), water-legal authorization (24 part III of Annex), submission of a document stating giving a power of attorney (Art. 1, 1 point 1 of the Stamp Duty Act) are the examples of this category of the stamp duty subject. In this case, the stamp duty may be considered in categories of the cost of running 
the economic activity, but exclusively in the situation when the entrepreneur submits the application connected with the costs of his economic activity.

Actions, that are subject to stamp duty, indicated as the second and the third categories, are the grounds for further detailed stamp duty assessment from its affecting undertaking and running economic activity point of view. The analysis should include a detailed list of the stamp duty subjects (categories of official actions carried out on the entrepreneur's request), the stamp duty rate and a catalogue of the object exemptions.

As far as the first issue concerns - the detailed list of the stamp duty objects - it has a double meaning. Both the kind of the official action that is subject to charge (for example, issuing a certificate, granting a licence) and the kind of economic activity, that the official action concerns are essential. The above proves the legislator's preference to some kinds of economic activities (if related with them official actions are not subject to the stamp duty or they are subject to relatively low amount) or the evidence of the restrictive relation with some spheres of activity (if the related with them official actions are subject to relatively high amount).

The subject exemptions are the element of the stamp duty construction, which also may prove the legislator's preference to some spheres of the economic activity. Unfortunately, it is difficult to find such subject exemptions that would be dedicated to entrepreneurs and would express a preference in relation to determined category of activity among other subject exemptions. In principle, the only example is the exemption from stamp duty the decision on entry in the register the entities running employment agencies, and carrying out entry in the register of the activity under control the entity producing registration plates (36 part I of Annex). The exemption is justified because of public benefits related with such activity. In explanatory statement to the Bill of 19 December, 2008 on amending the Employment Promotion Act and Institutions of the Work Market and on amending some other Acts (parliamentary printing 1196 of Sejm of the Republic of Poland VI term) the legislator explained that: 'it should be taken into consideration that the entrepreneurs who have declared the economic activity and by virtue of it they incurred some registration costs apply for entry in mentioned above register' (Sejm Rzeczypospolitej Polskiej, 2017). In connection with the above, there are not rational grounds for imposing on the additional barrier (costs), which will cause an increase of the costs of running the economic activity to such entrepreneurs. Collection of double charge from mentioned above subjects performing such a positive role on the work market (gaining the job and mobilization of unemployed people) is groundless.

Rates of stamp duty for actions carried out on request of the taxpayer-entrepreneur require the assessment in the context of the amount of the stamp duty rates by virtue of other actions, which are not related with the economic activity sphere, or which are related with other kind of economic activity. Clearly perceptible regularity is the fact that when the action is related with economic activity, it is charged with the stamp duty rate higher than in other cases - 
actions, that are not related with economic activity. It is especially noticeable in case of permits (authorization and licences). Thus, for example, the Act provides the stamp duty of 1PLN each $\mathrm{m}^{2}$ of usable area, not more than 539 PLN, by virtue of a permit issued on the basis of the building law regulations to build a building and building facilities connected with a building, which is designed for running the economic activity other than agricultural and forest activities; whereas for example, such permit to build a farm building for using in the farm is subject to the stamp duty of 14 PLN (9 part III of Annex); a permit to introduce the substance and energy into environment, issued on the basis of regulation on the environment protection in relation with the run economic activity is subject to the stamp duty of 2011 PLN, whereas such permit issued in other cases (which are not related with economic activity) amounts 506 PLN (40 part III of Annex). The key example is the stamp duty rate that amounts 82 PLN fixed for other than listed in the Annex permits (authorization, licences), but if such permits (authorization, licences) concern the carrying out economic activity the rate of the stamp duty amounts 616 PLN (44 Part III of Annex). The perceptible regularity is also the fact, that among actions related with economic activity, the actions related with the economic activity causing the highest hazard for society (for example, activity connected with production of alcoholic drinks) are charged with the highest rate. The risks of covering the social cost resulting from such activity are a burden for the State, that seems to be a justification for comparatively high rates of stamp duty in such cases. On the one hand, the amount refers to potential costs of the State related to removal of the social consequences resulting from the activity, on the other hand, it creates a specific financial barrier that require taking the amount into consideration in the stage of making decision on undertaking such activity. Another criterion differentiating the amount of the stamp duty rates can also be the range of the run activity defined as a source of potentially high income by virtue of activity (for example, activity of the banks).

Next regularity in the range of influencing the stamp duty on undertaking and running economic activity is the fact that both official actions carried out in the stage of the beginning and carrying out the economic activity are subject to stamp duty. The detailed list of actions being subject to charge does not include actions connected with closing running the economic activity. In this case, stamp duty charged in the stage of undertaking economic activity is of special importance as this charge is a requisite of the economic enterprise in general. In this range the stamp duty makes an administrative barrier in financial dimension connected with the legal-administrative forms of the economic activity control. Such actions as decisions on entering in different kinds of registers (that are a requisite of running a specific kind of activity, for example, entry in a register of the insurance agents 34 part I of Annex), entry in a register the regulated activity (35 part I of Annex) and different kinds of permits to run activity (for example, to fund the bank in a form of a joint-stock company - 15 part III of Annex) are among actions being subject to stamp duty. 
In the stage of carrying out of economic activity, the law regulations impose different kinds of duties on the entrepreneur, among other things the duties connected with official actions of public administration, that are also subject to stamp duty. They are actions connected with the entrepreneur's activity in progress (different kinds of certificates and administrative decisions, among other things, for example, connected with a building process). It is appropriate to include in this category a special stamp duty subject that is submitting a document that states giving the power of attorney or procuration. Activities connected with special entrepreneur's obligations, imposed on the entrepreneur on the basis of law regulations, for example, connected with environment protection, make the second category. In such situation the entrepreneur is treated as a professional subject towards whom higher requirements in the issue of standards related to running economic activity may be imposed; while the fiscal burdens resulting from regulations connected with environment protection refer to so-called outside costs of the activity, where the environment suffers the consequences of the activity (for example, stamp duty of 105 PLN for giving a certificate stating that the building structures and technical devices designed to carry out the given an economic activity fulfil the requirements specified by the regulations on environment protection. Next category of official actions fulfilled on the entrepreneur's request make the ones related with a specific category of activity and resulting from its nature, not from the fact of undertaking and running the economic activity (for example, a range of official actions have been undertaken in connection with activity in the field of the agents for protecting plants, for example, decision on the issue of giving authority to research on efficiency of the agent for protecting plants, 36b part I of Annex). It is also appropriate to notice the category of official actions being subject to the stamp duty related with fulfilment of the entrepreneur's obligations as a taxpayer of different taxes. The stamp duty in such case makes the additional cost connected with other levy burdens, being a consequence of obligations resulting from the tax control on grounds of other taxes imposed on the entrepreneur (for example, stamp duty of 170 PLN (amount) be virtue of acknowledging the receipt of application of registration in excise tax, 15 part I of Annex, stamp duty of 170 PLN by virtue of acknowledging the registration the taxpayer of the tax on goods and services as an active VAT taxpayer or an exempted from VAT taxpayer - 16 part I of Annex).

\section{Lines of influencing the Stamp Duty Act on undertaking and running economic activity - attempt to assess. Results of research}

From the entrepreneur's point of view the stamp duty is an objective cost of the carried out activity. At the same time, the stamp duty is not only a cost from the economic point of view, but it also is an expenditure that can be classified as the tax deductible expenses on grounds of the personal income tax 
and the income tax on legal person. According to Art. 22 of the Act on Personal Income Tax (1991), tax deductible expenses are the costs incurred in order to attain income, retain or secure the income, except the costs listed in Art. 23. Considering the fact, that in Art. 23, which is a closed catalogue of expenditure, that is not the tax deductible expenses, the stamp duty has not been listed, it may be taken as the tax deductible expense. However, the stamp duty has to fulfil the criteria listed in Art. 22 Paragraph 1 of the Act, so it has to be incurred in order to attain income, retain or secure a source of income. The fact of incurring the stamp duty has also to be proved. Article 15 of the Act on Income Tax on Legal Persons (1992) includes the analogous regulation. The stamp duty fulfils the above criteria. From the entrepreneur's point of view, the stamp duty is the cost related to the exercise of the State administrative machine in most administrative issues connected with undertaking and running economic activity. It is important that, as far as from a procedural point of view, starting the actions of the administrative machine depends on the entrepreneur's willing (official actions fulfilled on require are subject to stamp duty), in fact such obligation is imposed by the regulations on the rage of different areas of law system, especially the regulations on the rage of the economic activity control. Thus, obligation by virtue of a stamp duty is a derivative of administrative duties imposed on the entrepreneur on the basis of the individual Acts and it is the additional administrative barrier of financial nature (Antonów, 2016b, pp. 685-702). The basic purpose of each public duty is the fiscal purpose. Nevertheless, the legislator also exercises of public duties in order to fulfil non-fiscal purposes - the economic and social purposes. In the case of public charges, the stamp duty among other things, the purposes should be of special importance. Assuming that the stamp duty as an administration charge with the widest objective and subjective scope is a fiscal barrier in access to the civil service, it is appropriate to ask the question about the purpose of making the barrier. It is appropriate to search for the justification of such action in the economic politics of the State. By establishing the financial barrier in access to civil services the State makes an attempt to control unjustified occupying of the administrative agencies as well as it makes an attempt to influence the entrepreneur's decisions on undertaking economic activity, its kind and range. This takes place by creating the structure of the stamp duty subject, rates and exemptions. On the other hand, from the entrepreneur's point of view, the stamp duty is not solely the form of payment for official actions. First of all, the stamp duty refers to benefits resulting from the fulfilled action or it is a form of 'taxation' of potential incomes by virtue of the run activity conditioned by official action of the public administrative agency - granting a decision, a permit, a licence or carrying out entry in the right register. The observation have an established entry in the doctrine, where among charges, the category of charges related to the defined benefits obtained by paying them people, has been distinguished (Jaśkiewiczowa, 1964, p. 8). The stamp duty may also be assessed in these categories, especially in the range, in which it is a burden to entrepreneurs. 
For the sake of collecting stamp duty by virtue of taking the right individualized decisions relating to an individual person the stamp duty fulfils the role of refunding the expenditure incurred by the public agency for such activity in the less degree, the stamp duty is more the payment for individual benefit, which the person derives from the decision (Jaśkiewiczowa, 1964, p. 7; Adam, 1962, p. 77). In the highest degree, it concerns the stamp duty by virtue of issuing a permit (authorization, licences). Potential earning possibilities resulting from the nature of the run activity on the basis of the received permit (authorization, licences) may be the justification of collecting stamp duty and the determinant of establishing the stamp duty amount (on benefits resulting from the actions coming within the stamp duty as the grounds for establishing this stamp duty) (Gliniecka, 2007, p. 34). In the doctrine, this regularity is an argument for the circumstances when it is appropriate to include the stamp duty by virtue of issuing a permit (authorization, licences) to expenditures conditioning and burdening the undertaking of economic activity. The most vivid for this issue is a notion, which assumes that a stamp duty for giving a licence as a charge connected with actions concerning the economic turnover, becomes a cost factor of the turnover (Gliniecka, 2007, p.81), and that a stamp duty for permits connected with the earning activity, in a sense becomes a flat-rate taxation on the future activity and it may be recognized as a peculiar form of the flat-rate income tax collected in advance (in accordance with anticipation) (Jaśkiewiczowa, 1964, p. 31).

The official action - giving a permit (authorization, licences) has also been subjected to economic analysis, where the costs (charges) connected with obtaining such type of decision of assent, conditioning the undertaking specific activity are assessed as one of the factors influencing on the entrepreneur's decisions in this range. Taking into consideration the benefits resulting from the obtained permit, it is appropriate to treat the stamp duty conditioning obtaining the permit not only as a peculiar administrative barrier, but wider — as a barrier on undertaking the specific kind of economic activity - the barrier at entering a market. In the doctrine barriers at entering a market are defined in different ways. Assuming the most straightforward definition, it can be admitted that everything that makes impossible for entrepreneurs to enter the market, if the entering is socially profitable; or everything that makes impossible for entrepreneurs to fund immediately a new business on the market, among this the costs, that the entrepreneurs who want to enter the market incur, but the entrepreneurs existing on the market do not incur, are such barriers (Kabza, 2014, p. 147). Defined in such way barriers at entering the market have a discouraging effect on entrepreneurs, making the economic activity unprofitable or less profitable. In the licence case among other things, the stamp duty for giving a licence has a discouraging effect as a barrier at entering the market (Kabza, 2014, p. 147). Economic analysis of the licence shows that necessity of paying a stamp duty for giving the licence, as well as necessity of going through the right administrative procedures in this range changes the economic account 
of the subject making decision on initiating economic activity. If the costs connected with such decision are too high in comparison to the expected profits, the entrepreneur will withdraw from undertaking economic activity (Kabza, 2014, p. 145). The function of the stamp duty by virtue of giving a permit (authorization, licences) understood in such way confirms the truth of statement that the amount of stamp duty refers not only to actual administrative expences for carrying out the official actions connected with issuing the decisions, but first of all, to the potential profits by virtue of the activity carried out on this grounds. Thus, it expresses the financial barriers connected with undertaking economic activity, that are possible to overcome by the entrepreneur. Hence, in the doctrine the stamp duty is defined as an indirect charge, that it is appropriate to understand in such way, that a payment capacity of the person obliged for paying it is assessed only indirectly, by the importance of the action connected with the charge for paying it (the charge) person (Adam, 1962, p. 81; Gliniecka, 2007, p. 29).

The elaborated example of a stamp duty for issuing a permit (authorization, licences) although the most vivid and the most typical for a taxpayer-entrepreneur does not cover thoroughly the influence of the public levy on undertaking and running economic activity. Other categories of official actions that are subject to stamp duty fulfilled in a stage of undertaking and running economic activity also affect the entrepreneur's decisions, and it is appropriate to analyse them in the context of their economic effects. It is appropriate to mention the attitude of Constitutional Tribunal stated on the issue of incompatibility with the Polish Republic Constitution Act on Creating and Working of Shopping Centres of Big Surfaces (2007) as an example of such stamp duty assessment. Article 14 of the Act introduced amendments in the Annex to the Stamp Duty Act in part III - after point 43 were added points $43 \mathrm{a}$ and $43 \mathrm{~b}$, on the basis of which: a permit issued on the basis of creating and working of shopping centres of big surfaces were subject to the stamp duty of 25 PLN for each square metre of the sale surface, not more than $0.5 \%$ of the declared investment value pointed in a petition mentioned in Art 4 of the Act on creating and working of shopping centres of big surfaces; whereas the amendment of the permit was subject to the stamp duty of $50 \%$ of the rate collected by virtue of issuing a permit. The Constitutional Tribunal in context of violation of the principle of the freedom of economic activity was considering among other things a high stamp duty by virtue of permits, issued on the basis on regulations on creating and working of shopping centres of big surfaces, assessing the stamp duty as an interference in freedom of running economic activity as an obstacle in running economic activity in the range of shopping centres of big surfaces (Judgement of Constitutional Tribunal of 8 July 2008, K 46/07).

Analysing the place of the stamp duty in a structure of expences of the undertaking and running economic activity subject, the following regularities can be indicated. The stamp duty is included in the same category as the taxes; stamp duty is a category of public burdens for an entrepreneur. As the taxes, it 
is a burden for an entrepreneur both in the stage on undertaking and running economic activity (in the doctrine, it is assumed the assessment of the taxes influence on economic activity in three terms: the influence on undertaking, running and closing the economic activity ${ }^{1}$. However, taking into consideration the nature of a stamp duty as an administration charge, it is appropriate to notice its other nature comparing to the taxes - its nature as the cost of running economic activity. The stamp duty may be of single or repeatable nature, but devoid of regularity well-regulated by the regulations of law as in the case of taxes paid in the system of advance monthly payment. As far as the single burden of the stamp duty seems to be minimal in comparison with tax burdens, the global assessment of the single costs by virtue of charges incurring by virtue of different official actions in the outlook for a longer time may become a considerable, regular expense. It goes on in the situation when the entrepreneur appoints a commercial proxy and each time he is obliged to pay a stamp duty by virtue of applying a document stating giving the procuration. Moreover, it is appropriate to emphasize bigger importance of non-fiscal functions of a stamp duty in comparison with taxes. It results from combination of a stamp duty with the administrative procedures indicating that absence of completion of obligation by virtue of a stamp duty slows down or makes impossible undertaking different administrative actions in the subject of economic activity.

Analysing the influence of a stamp duty on undertaking and running economic activity it is appropriate to notice that considering the legal construction of a stamp duty, in contrast to the case of the taxes, it is no possible to make economic decisions that could influence on minimization of the entrepreneur's costs by virtue of the stamp duty within the actions called 'management through taxes'. Management through taxes means making decisions in the range of different spheres of the entrepreneur's economic activity related with tax effects. The purpose of managing through taxes is to minimize the taxes that burden enterprises in short and long time horizons. As far as charges, just as the taxes are a limitation of financial possibilities of an enterprise, after all, with reference to the stamp duty it is difficult to speak about management possibility with the effect of minimization of related with this costs (Sokolowski, 1995, pp. 9-11). The stamp duty construction almost excludes any possibilities of taking actions that could influence on minimization (both in short and long time horizons) of burdening the enterprise by virtue of it. The cost is of fixed nature in such effect that distinct from the tax burdens, the taxpayer is devoid of possibility of making decisions on the range and method of running the economic activity that could affect decrease of burdens by virtue of it. The more, so as to a charge degree, the necessity of carrying out most of official actions by the entrepreneurs is forced by the legislator on grounds of regulations of different legal acts, compliance with which guarantees the lawfulness of running the economic activity.

\footnotetext{
${ }^{1}$ Such division has been assumed by, for example Borszowski (2010, p. 441)
} 


\section{Conclusion}

Public charges are one of the public burdens imposed on entrepreneurs. The charges are one of the costs of economic activity and this means that they may form the entrepreneurs' decisions on the subject of the run by them activity. Therefore, analysis of the public levies affecting undertaking and running economic activity should include not only taxes, but also public charges. The legal construction of the charges, first of all their subject, exemptions and amount decides on trends of influencing the payments on undertaking and running economic activity. The above settlements of general nature have been confirmed by the detailed analysis of the stamp duty construction. The stamp duty is a charge collected by virtue of actions carried out on request. In the detailed list of actions being subject to a stamp duty there are actions that may concern or entirely concern undertaking or running economic activity. They are different kinds of official actions, among other things mainly permits and licences that are a requisite of the initiating of economic activity. The certain regularity is the fact, that the rates of stamp duty by virtue of actions carried out on an entrepreneurs' request on the subject of run by them activity are higher in comparison with the rates by virtue of other actions. One may also notice the tendency appearing in differentiating the amount of a stamp duty according to a kind of economic activity, which the action refers to. Official actions connected with economic activity generating the potentially highest incomes or generating the highest public costs (for example, activity connected with alcohol production) are subject to stamp duty of the highest amount. It proves the non-fiscal importance of a stamp duty as an instrument of economic policy of the State in relation to entrepreneurs.

\section{References}

Adam, L. (1962). Podatki i optaty w kapitalizmie. Warszawa: PWE.

Antonów, D. (2014). Pojęcie opłaty administracyjnej w polskim języku prawnym i prawniczym. In Z. Ofiarski (Ed.), XXV lat przeobrażeń w pawie finansowym i prawie podatkowym - ocena dokonań i wnioski na przysztość. Szczecin: Wydawnictwo Uniwersytetu Szczecińskiego.

Antonów, D. (2016a). Opłaty publiczne w działalności gospodarczej na przykładzie branży transportu drogowego. Annales Universitatis Mariae Curie-Sktodowska. Sectio H: Oeconomia, 50(1). doi:10.17951/h.2016.50.1.537.

Antonów, D. (2016b). Świadczenia pieniężne związane z działalnością administracji. In E. Ura, E. Feret, \& S. Pieprzny (Eds.), Jednostka wobec dziatań administracji publicznej. Rzeszów.

Banaszak, B. (2012). Konstytucja Rzeczypospolitej Polskiej. Komentarz. Warszawa: C.H. Beck.

Borszowski, P. (2010). Działalność gospodarcza w konstrukcji prawnej podatku. Warszawa: Wolters Kluwer. 
Ciapała, J. (2001). Konstytucyjna zasada wolności działalności gospodarczej. Ruch Prawniczy, Ekonomiczny i Socjologiczny, 4.

Gliniecka, J. (2007). Optaty publiczne w Polsce. Analiza prawna i funkcjonalna, Bydgoszcz-Gdańsk: Oficyna Wydawnicza Branta.

Jaśkiewiczowa, J. (1964). Elementy podatkowe opłat publicznych w Polsce. In Z. Jaśkiewicz (Ed.), Studia podatkowe i budżetowe. Toruń: UMK.

Judgement of Constitutional Tribunal of 8 July 2008. K 46/07 (Dz.U. 2008 nr 123 poz. 803) (Poland).

Judgement of WSA in Wrocław of 28 September 2010. II SA/Wr 387/10. Lex No 755580.

Kabza, J. (2014). Koncesje i zezwolenia. Analiza ekonomiczna. Warszawa: Wolters Kluwer.

Konstytucja Rzeczypospolitej Polskiej z dnia 2 kwietnia 1997 r. [Act of 2 April 1997, the Polish Republic Constitution] (Dz.U. 1997 nr 78 poz. 483) (Poland).

Krzywoń, A. (2011). Podatki i inne daniny publiczne w Konstytucji Rzeczypospolitej Polskiej. Warszawa: Wydawnictwo Sejmowe.

Mastalski, R. (2003). Autonomia prawa podatkowego a spójność i zupełność systemu prawa. Przegląd Podatkowy, 10.

Mastalski, R. (2014). Prawo podatkowe. Warszawa: C.H. Beck.

Sejm Rzeczypospolitej Polskiej. (2017). Retrieved 24.01.2017 from http:// www.sejm.gov.pl.

Sokołowski, J. (1995). Zarządzanie przez podatki. Warszawa: PWN.

Ustawa z dnia 11 maja 2007 r. o tworzeniu i działaniu wielkopowierzchniowych obiektów handlowych [Act of 11 May 2007 on Creating and Working of Shopping Centres of Big Surfaces] (Dz.U. 2007 nr 127 poz. 880) (Poland).

Ustawa z dnia 15 lutego $1992 \mathrm{r}$. o podatku dochodowym od osób prawnych [Act of 15 February 1992 on Income Tax on Legal Persons] (Dz.U. 1992 nr 21 poz. 86) (Poland).

Ustawa z dnia 16 listopada 2006 r. o opłacie skarbowej [Act of 16 November 2006 on Stamp Duty] (Dz.U. 2006 nr 225 poz. 1635) (Poland).

Ustawa z dnia 2 lipca 2004 r. o swobodzie działalności gospodarczej [Act of 2 July 2004 on Freedom of Economic Activity] (Dz.U. 2004 nr 173 poz. 1807) (Poland).

Ustawa z dnia 23 kwietnia 1964 r. - Kodeks cywilny [Civil Code of April 23, 1964] (Dz.U. $1964 \mathrm{nr} 16$ poz. 93) (Poland).

Ustawa z dnia 26 lipca $1991 \mathrm{r}$. o podatku dochodowym od osób fizycznych [Act of 26 July 1991 on Personal Income Tax] (Dz.U. 1991 nr 80 poz. 350) (Poland).

\section{Acknowledgements}

Author contributions: author have given approval to the final version of the article. 
